\title{
Towards Mathematics Education as Part of Ethical Citizenship Under COVID-19
}

\author{
Sikunder Ali \\ Norwegian University of Science and Technology (NTNU)
}

Mathematics is becoming increasingly influential in formatting social systems in modern societies. When mathematics (as an application) is integrated into social systems, it not only describes them but can also transform/regulate them. This paper presents some ethical consequences of nexus of mathematics with social systems specially as a reflexive response to COVID-19 (with its increasingly changing landscape of its mutations) situation that we are experiencing now. The consequences of these decision-makings based on mathematically formatted structures on both social systems and on individual levels will be related to social, political, and ethical perspectives. This brings implications for how ethical citizenship within a democratic polity can critically engage with mathematically formatted structures such as reasoning based on mathematical models enlisted within social systems. In other words: how can we conceive of mathematics education as part of ethical citizenship under COVID-19 so that social justice principles can be foregrounded and practised in all spheres of life?

Keywords: ethical citizenship, inclusion and exclusion, mathematics education, social systems, COVID-19

\section{CRITICAL SOCIAL CONSEQUENCES OF PERFORMATIVE MATHEMATICS}

Historically intermixing of science/technology has brought serious considerations for situating mathematics within ethical landscape (Ernest, 2018). For example, the high-stake Manhattan Project (as an exemplification of this science/technology nexus) in USA led to create counter force to end the Second World War. At the same time technology as realized principles of science/mathematics applied to social systems has brought perpetual challenges for education of critical and ethical citizenship in modern globalized societies that we live in. Moreover, intensive processes of digitalization are transforming many aspects of diverse social systems by powerful governments and high-tech companies (e.g., Google, Facebook, Microsoft etc). These technological transformations (supported by mathematically formatted black boxes) are being guided and controlled by experts and expert systems have brought variety of ethical questions for practices of inclusions of exclusions of citizenships (Skovsmose, 2020). Here certain types of citizens (clearly economically well-off) are being prioritized as responsible (as demonstrated through network of classificatory schemes (often based mathematical algorithms) (Skovsmose, 2020). Critical question is: how are citizens with less privileged and disadvantaged background being included and excluded through these embedded mathematically formatted structures within social systems? 
Baber (2007) has identified that numbers and functioning of liberal democracy are linked together; that is the extensive uses of numbers have made possible the liberal democracy to function the way it functions in the current political landscape. Furthermore, how numbers are being used in making subtle government of citizens within liberal democratic tradition possible and how this governmentalization process conceals its own governing strategies? This double nature of relationship between governmentalization and the numbers can raise importance of developing a critical approach, mathemacy, needed for reflexive judgement of citizens within democratic societies in today's increasingly globalized world. Under these conditions, literacy and numeracy become two important aspects that prepare citizens to become effective in handling varied demands of their life in the complex modern societies.

Societies are increasingly operating in in-secure environments. Nature of the problems are becoming requires one to face uncertainty. Here tools with deterministic calculations might not help us much to deal with situations of uncertainty and risks.

For example, securing health in a modern society is receiving increasing attention. There are different insurance companies that offer variety of products to secure health of a person. Often these companies operate on models devised through statistical methods or knowledge derived through empirical methods. Here the companies use several indices to inform their decision-making process to formulate packages suitable for securing health coverage of people with different age groups. One of the common indices the health insurance companies use is Body Mass Index (BMI). This is defined as ratio between mass in kilogram divided by square of the height in meter squares. Normally this index is used to classify the obesity of the population of a country. Usually, this norm of obesity in a particular is used as a reference point to compare the body mass index of the person to determine chances of longevity or early or later death of the person. For example, in USA there are companies ask a person who seeks their insurance product to continually monitor their BMI on a regular basis. If this measure is not under within a limit, then they are advised to make decision on changing their lifestyle or eating so that they bring their BMI to the acceptable or agreed level. If not, then they must either pay expensive premium or leave the company health coverage.

In other words, socio-mathematical-models bring implications for the general health of a person or securing the health coverage of a person. Question arises: how can one support citizens so that they can develop their entitlements to read and interpret their life world in a critical way? How can citizens find opportunities to give an active input to decision-making processes of companies and state concerning security of their health or minimizing risks their healthy life?

If one can relate this discussion on citizens and governing of citizens through different tools of governing citizens by the state or state-like actors under the conditions of modernity or in post modernity, one can find a gap in literature in Mathematics Education where there has not been much serious attempts made to prepare citizens to become critical of the world in which numbers are colonizing their world with increasing intensity and expertise is increasingly coding their claims into the language that is often inaccessible to people. Under this situation, it becomes imperative that there should be ample opportunities available where citizens develop their competency in giving input to authorities who are making claims while using numbers heavily. This also raises the importance of combining literacy and numeracy together to form a mathemacy (See, Baber (2007) or to bring attention to critical mathematics education (see Skovsmose, 1993; 1994 and 2004). In this background, following research questions become prominent when one thinks of relation between education of mathematics and citizenship:

- In what ways mathematical structures through the process of objectification are constituting the lifeworld of citizens in societies under conditions of modernity and globalization?

- How can one develop educational processes that can facilitate citizens to become critical on formation process of mathematical structures as part of their entitlement to critical mathematical competence (namely mathemacy)?

- What are the implications for preparation of future mathematics teachers in making them critical on these formative mathematical structures? 
Within this context of mathematics as a part of regulating modern society, this paper offers some reflections towards understanding and articulating the links between mathematics and ethics within social contexts where mathematical structures make certain actions acceptable/legitimate and other actions undesirable. The consequences of these decision-makings based on mathematically formatted structures on both social systems and on individual levels will be related to social, political, and ethical perspectives. Here main research question is: How can we conceive of mathematics education as part of ethical citizenship under COVID-19 so that social justice principles can foregrounded and practised in all spheres of life?

\section{ETHICAL CITIZENSHIP AND IMPLICATIONS FOR INCLUSION AND EXCLUSION}

Citizenship is normally interpreted in terms of rights/obligations granted by legal framework prevalent in a nation state. Citizenship can be considered as way to participate in the political decision-making process by voting or electing someone who represents political and economic interests of groups (Rose and Miller, 1992). The participatory notion of citizenship is advanced as way to give more substance to legal notion of citizenship. Participation citizenship (as part of strong democracy (Benjamin (2003) presumes active engagement within political decision making at various social levels such as students deciding about the theme and topic that they want to investigate an interdisciplinary project in mathematics classroom where they can investigate how public money is being distributed in terms of securing access of computers among pupils at various grades in schools. The engagement of pupils in such projects can encourage pupils to raise issues of time that each of them can spend on working with data machines, how use of these data impact in projecting graphs and how these graphs can be interpreted from different perspectives etc. At the macro level active participatory citizenship can be conceived of as ways for citizens to engage in debate with health authorities so that they can sort out different meanings and interpretations that goes with Reproductive number $R$ as a way not only to contain the further spread of COVID-19 virus but also define and regulate both conduct of citizens and businesses. Here citizens can take a critical stand on high stakes mathematical models (enabled by science/technology structured with socio-economic and political contexts) (Skovsmose, 2020; Porter 1996). Ethical citizenship (Brooks 2014) as participation of citizens in identifying and upholding common goods in society as mutual responsibility to each other to secure an inclusion of disadvantage individuals and groups in society. Here participatory citizenship can be conceived of as ethical citizenship as this citizenship will allow us to create a socially inclusive space so that voices of all the citizens are included and negotiated in taking decisions on issue of opening and closure of societies under grip of Covid 19 so that negative consequences of decisions based on performative mathematical structures on polity in general and vulnerable population in general be taken into full account. Among others, one can identify two challenges that COVID-19 has brought in reconceiving mathematics as a tool that format social systems and need for ethical citizenship:

First, the issues of inclusion and exclusion in all arenas of life (jobs, education, health, economic, social political, cultural etc) have been intensified under COVID-19 pandemic. So, question arises how we can conceive mathematics education research field so that all the exclusionary practices in above spheres could be considered and notions of social justice can be re-imagined so that everyone irrespective of their background (social, economic, historical, cultural, birth, gender, and race etc) be included and get rights to secure human dignity (Adorino, 2014) under pre-carious situations this pandemic has created. For example, every human being has right to access vaccine that can protect one from COVID-19 virus as well as similar viral attacks on human beings in future.

This development and distribution of vaccine should not be seen from business economic models but could be based on securing dignity of every human being and all other beings on planet Earth. Here mathematics education could be considered as a tool to fight against all forms of racism and discriminations which classify for example black people as not equal worth as compared to their white counterparts (evident through Black Lives Matter movement in USA under pandemic) (Gutstein, 2006). 
Second, mathematics as a tool social/contextual embeddedness can allow us to re-imagine alternate economic models that secure well-being, social security to re-conceive welfare states that guarantee successful and dignified living for everyone in societies we live in. That means that foundations of rationalities especially economic rationalities should be reimagined so that idea of profit associated with efficiency and maximization be discarded instead a society based on care and trust be established. That is education of mathematics does require strong ethical component as part of securing human dignity under COVID-19. That is mathematics for ethical citizenship as way to create inclusionary social justices for all so that grand challenges such as COVID-19 pandemic and devastating existential crises such as environment crises that we all human being must tackle collectively. That is colossal damages of over five million precious human lives could have been avoided through ethical citizenship that emphasizing the common good as a mutual responsibility and this brings our serious attention to take all ethical aspects that mathematics as part of enlisted tool of socio-political importance within intermixing of science and technology under conditions of modernity. Not securing vaccination to all people around the globe is starting new threat of deaths due to new variant omicron or many other unforeseen variants yet to come into action. This points out the importance of re-looking and re-evaluating our ethical engagements with the world we live in and secure the well-being of all who inhabit our planet Earth and beyond!

\section{REFERENCES}

Adorino, R. (2014). Human dignity and human rights. In H. ten Have \& B. Godijn (Eds.), Handbook of Global Bioethics (pp. 45-57). Dordrecht: Springer.

Baber, S. (2007). Interplay of Citizenship, Education and Mathematics. An unpublished PhD dissertation submitted as part of PhD fellowship at the Department Education, Learning and Philosophy Aalborg University Denmark.

Benjamin, B. (2003). Strong Democracy: Participatory Politics for a New Age. Berkeley: California University Press.

Brooks, T. (2014). Ethical Citizenship: British Idealism and the Politics of Recognition. Basingstoke: Palgrave Macmillan.

Ernest, P. (2018). The Ethics of Mathematics: Is Mathematics Harmful? In P. Ernest (Ed.), The Philosophy of Mathematics Education Today (pp. 187-216). Dordrecht: Springer.

Gutstein, E. (2006). Reading and Writing the World with Mathematics: Towards Pedagogy of Social Justice. New York: Routledge.

Porter, P. (1996) Trust in Numbers: The Invention of Objectivity. Princeton University Press, Princeton.

Rose, N., \& Miller, P. (1992). Political Power Beyond State: Problematics of Government. British Journal of Sociology, 43(2), 172-205.

Skovsmose, O. (1993). The Dialogical Nature of Reflective Knowledge. In S. Restivo, J. Bendegem, \& R. Fisher (Eds.), Math Worlds: Philosophical and Social Studies of Mathematics and Mathematics Education. New York: State University of New York Press.

Skovsmose, O. (1994). Towards a Philosophy of Critical Mathematics Education. Dordrecht: Kluwer Academic Publishers.

Skovsmose, O. (2005). Travelling Through Education: Uncertainty, Mathematics, Responsibility. Rotterdam: Sense Publishers.

Skovsmose, O. (2020). Banality of mathematical expertise. ZDM, 52(2020), 1187-1197. 